\title{
Interjogo de imaginação e emoção: estudo de um processo musicoterapêutico
}

\author{
Denise de Camargo \\ Yara Lucia M. Bulgacov \\ Rosemyriam Cunha \\ Universidade Federal do Paraná
}

\begin{abstract}
Resumo
Este trabalho é um estudo de caso que busca relacionar a narrativa musical de uma senhora idosa e sua história de vida. Os dados foram coletados num processo de musicoterapia, num interjogo entre imaginação e emoção. O objetivo da reflexão é entender como as atividades criativas podem comunicar significados e sentidos construídos nas interações sociais. O trabalho apóia-se na teoria sócio-histórica e pretende contribuir para a construção teórica da Psicologia e da Musicoterapia contemporâneas. Vygotsky e Bruner foram os autores que embasaram as presentes reflexões, como também Bruscia e Ruud, teóricos da musicoterapia. Os resultados demonstram que as atividades expressivas na forma de narrativa musical possibilitam a expressão dos sentidos constituídos nas interações sociais e a organização das experiências do ser humano.

Palavras-chave: narrativa musical; musicoterapia; imaginação e emoção.
\end{abstract}

\begin{abstract}
Interplay between imagination and emotion: a study of a musictherapy process

This is a case study which aims to establish a relationship between na elderly woman's music narrative and her life story. Data was collected during a music therapy process which interacted emotion and imagination. The objective was to comprehend how creative activities can communicate sense and meaning obtained during the social interactions. Based on historical-social theory, this study's purpose is to contribute to the Psychology's and Music Therapy's theory which seeks to understand the human being in relation to his/her social-cultural relationships. Vygotsky and Bruner contributed to these reflections as well as music therapist experts as Bruscia and Ruud. The results demonstrated that the creative activities of musical narrative form can express sense and meaning and organize human being experiences.
\end{abstract}

Keywords: musical narrative; music therapy; imagination and emotion. 
O trabalho aqui apresentado é um estudo de caso que busca analisar a relação entre a narrativa musical de uma senhora idosa e sua história de vida. A expressão de suas experiências deu-se no decorrer de um processo musicoterapêutico, numa dinâmica de apropriação de significados e sentidos por meio do interjogo de imaginação e emoção.

Numa interface entre psicologia e musicoterapia, o presente estudo parte de considerações que se apóiam na teoria histórico-cultural e pretende contribuir para a construção teórica da psicologia contemporânea, a qual busca entender a constituição do sujeito.

O objetivo desta reflexão é entender como as atividades expressivas podem comunicar significados e sentidos construídos durante as interações sociais. Para atingir esse fim considerou-se o estudo da emoção e da imaginação tendo como referência Vygotsky (1999). Nesse caminho também refletiu-se sobre o papel da narrativa no processo de organização dos sentimentos, na medida em que, ao compartilhar com o outro nossos sentidos e intencionalidades, estamos reconstruindo nossas vivências históricas. Para tanto, buscou-se as contribuições de Bruner (2000).

A Musicoterapia será tomada, nesse contexto, como a aplicação científica do som, da música e do movimento por meio da escuta e execução. Teóricos desta área também colaboram com a reflexão, entre eles Bruscia (2000) e Ruud (1990).

Nesse sentido, a linguagem musical ${ }^{1}$, mobilizando emoção e imaginação, foi a forma de comunicação utilizada para estimular a expressão dos significados e sentidos que essa senhora construiu nas inter-relações durante seu percurso de vida .

A escuta e a execução de canções, ações predominantes de Chiquita - nome fictício adotado para preservar sua identidade - durante as sessões musicoterapêuticas, foram veículos de sua expressão musical. Assim, as letras das suas canções, a sequiência de apresentação destas e o ritmo das músicas estão sendo considerados como forma de expressão de seus sentidos pessoais, como narrativa musical de sua história de vida.

Pretende-se, desse modo, aproximar os pensamentos de Bruner (2000) e Vygotsky (1990) nas contribuições que ambos podem oferecer, no que tange a considerar a cultura como um elemento interpretativo que descreve nossos pensamentos, ações e modo de viver, e também em relação à lei do signo emocional comum, que aponta para a união entre si dos elementos culturais que nos causam efeitos emocionais semelhantes. Portanto, as imagens e os sentidos objetivados por meio da narrativa musical tendem a se unir, formando um conjunto representativo dos sentimentos, por possuírem um tom afetivo em comum.

Parte-se do pressuposto básico de que a prática musicoterapêutica proporciona a emersão de um repertório sonoro-musical revelador dos sentidos afetivos da pessoa. Esse repertório vem matizado da trajetória de vida da pessoa que se expressa, revelando as transformações ocorridas num espaço de tempo, que é o tempo de sua própria vida, através das mediações com o meio em que vive. Desde as canções de ninar que ouviu, as canções de roda que brincou, as melodias da juventude que embalaram sonhos e frustrações, até as melodias eleitas no momento atual, trata-se de um processo identificatório em constante transformação que se concretiza sonoramente.

Considera-se a música, no contexto deste estudo, como uma expressão social construída com os elementos da cultura e as características do tempo histórico em que se insere o homem que a expressa. Expressão criativa que revela os valores de humanidade e sensibilidade do homem social, constituindo-se como expressão de significados do ser humano. A música como atividade expressiva é um dos meios de alargar a experiência emotiva do homem, não só objetivando sentimentos que lhe são conhecidos, como também revelando e assimilando por meio da compreensão sentimentos novos que antes eram desconhecidos (Teplov, 1977).

A música como experiência artística propicia, portanto, o descobrimento do plano mais interno, profundo e oculto do pensamento. Partindo dessa tese, introduzimos o pressuposto de que a experiência musical pode se transformar em um meio de nos aproximarmos da trama afetivo-volitiva oculta atrás do pensamento, trama esta apontada por Vygotsky no final do texto Pensamento e Linguagem (1993).

\section{CONCEITO DE SIGNIFICADO E SENTIDO}

Segundo Vygotsky (1993), o pensamento verbal apresenta-se como um conjunto dinâmico e complexo em uma série de planos mais externos até mais internos. Na prática o caminho é: parte do motivo ou intenção - necessidade, interesses e impulsos, emoções - que desencadeia o pensamento, nesse estágio desprovido de forma lingüística específica. Passa então, para a formalização esse pensamento: primeiro sua formação e sua mediação na linguagem interna, logo mediado pelos significados das palavras e finalmente em palavras.

A linguagem interna guarda características peculiares de redução fonética e uma estrutura semântica singular que explicam a sua incompreensibilidade. Sua função não é a linguagem comunicativa em palavras ${ }^{2}$. Sua função não é a linguagem comunicativa, mas a mediação do próprio comportamento, "falar para si mesmo", como argumentou Vygotsky. O significado das palavras no plano interno adquire novas matizes e traços, configuram um sentido particular intraduzível na linguagem externa.

A linguagem externa supõe a transição do pensamento para a palavra. É um processo de materialização e objetivação do pensamento. A linguagem predicativa e particular deve transformarse em linguagem sinteticamente articulada e inteligível para os demais. O pensamento precisa da palavra para se realizar. A linguagem não é uma mera expressão de um pensamento, é uma forma necessária 
de realização do pensamento. $\mathrm{O}$ pensamento representa um todo mais extenso e volumoso que uma só palavra. O caminho do pensamento para a palavra passa pelo significado.

Vygotsky fez uma distinção entre significado e sentido. O significado da palavra é o que encontramos no dicionário, representa uma zona estável. $\mathrm{O}$ núcleo do significado dessa palavra estará submetido a constantes mudanças. Os significados que mudam em função do contexto são os sentidos das palavras. $\mathrm{O}$ sentido da palavra é mais amplo e mais dinâmico que seu significado.

Uma palavra situada num contexto tem ao mesmo tempo mais e menos significado que a mesma palavra fora do contexto. Tem mais significado porque se enriquece pelo contexto e menos porque o contexto limita e concreta seu significado abstrato. Essa contextualidade do sentido das palavras se reflete na flexibilidade ilimitada das relações entre sentidos e palavras. Palavras semelhantes podem adquirir significados opostos em função do contexto.

No diálogo oral começamos com o significado nuclear e em geral nos movemos, dependendo do contexto, para um significado individual, idiossincrático. $\mathrm{Na}$ fala interna, o processo começa pelo lado oposto, partimos do sentido particular dominado pelo pensamento ainda não-verbal. $\mathrm{Na}$ fala interna, o significado da palavra está dominado pelo sentido. O sentido da palavra é complexo e móvel e muda constantemente de pessoa para pessoa e de situações a outras para a mesma pessoa (Vygotsky, 1993, pp. 287-348).

\section{BREVES APONTAMENOS SOBRE A VIDA DE CHIQUITA}

Chiquita é uma senhora de 86 anos, de estatura baixa, olhos azuis e pele negra. Nasceu e viveu em São Paulo até mudar-se para Curitiba há oito anos, quando a família precisou do auxílio de uma clínica geriátrica para dar conta do estado confusional no qual ela se encontrava. Segundo o diagnóstico médico, Chiquita apresentava um quadro de delírio persecutório em relação à figura masculina, sintoma que tornou difícil sua convivência com a família.

Dados levantados em entrevista clínica revelam que, na juventude, ela trabalhou como doméstica e viveu um relacionamento amoroso com um homem de cor branca, de quem engravidou. Foi abandonada pelo rapaz e assumiu sozinha a gravidez.

Continuou trabalhando para criar sua filha. Esta estudou, empregou-se num serviço burocrático e lhe deu três netos. Quando não pôde mais trabalhar, foi morar com a filha. Com o passar do tempo, foi ficando reclusa, não saía mais de casa, circulava apenas no espaço entre seu quarto e a cozinha, convivendo apenas com as pessoas da família. Foi então que passou a apresentar os sintomas persecutórios.

Chiquita é uma pessoa profundamente religiosa, tem horários fixos para suas orações, num ritual que não permite atrasos nem alterações. Escuta o rádio o dia todo, sempre na mesma estação, embora diga que as músicas de hoje em dia são feias. Relatou que aprendeu a cantar suas músicas ouvindo a Rádio Tupi, em São Paulo.

Sua indicação para a musicoterapia se deu através da geriatra que a atendeu no ambulatório e teve por objetivo sua inserção num grupo e a conseqüente diminuição do isolamento de seis anos. Ela aceitou participar do trabalho, vinha para a sala de atendimentos ao ser convidada e retornava ao quarto da clínica ao término da sessão. Mesmo com a presença de quatro homens no grupo e desde que estes não se sentassem ao seu lado, ela participava da atividade realizando as consignas, ouvindo os outros integrantes e contribuindo com elementos musicais de sua vivência.

Esse primeiro processo durou o período de um ano e meio, tendo como resultado sua interação com os membros do grupo por meio de curtas verbalizações, comunicando seus valores e crenças e permanecendo na sala para tomar o lanche da tarde junto aos outros internos. Encontrava-se nesta fase de recuperação quando, vítima de um acidente com a vela que acendia para suas orações, sofreu queimaduras graves pelo corpo.

Lutou entre a vida e a morte por um ano. Recuperou-se, mas perdeu a marcha e desenvolveu, como sequiela, um problema cardíaco que lhe ocasiona uma tosse constante. Seu mundo, agora, é só o seu quarto. Seus objetos pessoais têm lugares determinados, sem possibilidade de mudança, seu dia é programado entre os horários de suas orações, e qualquer modificação em seu ambiente físico requer preparação prévia, caso contrário Chiquita apresenta alteração de comportamento, como ansiedade e agressividade.

Esse período de recuperação durou aproximadamente dois anos. Após seu pleno restabelecimento, foi solicitada novamente a intervenção musicoterapêutica, buscando-se a redução do quadro depressivo e do isolamento social. Voltei a atender Chiquita após o intervalo de três anos, agora individualmente, no seu quarto.

\section{MUSICOTERAPIA}

A arte dos sons sempre impressionou filósofos e terapeutas pelo seu poder de provocar experiências emotivas. Porém, foi observando a recuperação de neuróticos da Segunda Guerra que profissionais da saúde procuraram sistematizar os conhecimentos que fundamentaram a Musicoterapia. Desde então há escolas de ensino superior e associações pelo mundo afora sustentando a formação e prática desta profissão.

Podemos definir a musicoterapia seguindo a inclinação sociológica adotada por Ruud (1998), como uma intervenção terapêutica que tem por objetivo "aumentar as possibilidades de ação" da pessoa, tanto no âmbito individual como no social (p. 3). É uma intervenção que envolve a linguagem musical e corporal da pessoa como meios de propiciar ações que impliquem na apropriação da consciência 
de si e da sua trajetória histórica, ampliando suas possibilidades de interagir na realidade concreta em que se insere.

A comunicação musical, de acordo com Bruscia (2000), não é apenas um som não-verbal, mas inclui palavras, movimentos e imagens visuais. $\mathrm{A}$ comunicação musical pode ampliar e enriquecer outras formas de comunicação verbal e não-verbal. "Ter flexibilidade para mover-se do verbal ao musical e daí para canais de comunicação não-verbais é a marca da musicoterapia" (p. 71).

O mesmo autor sugere que a musicoterapia proporciona, através das atividades e experiências propostas nas sessões, a possibilidade de expressão de sentimentos e pensamentos. O musicoterapeuta, ao interagir com os participantes, visa estimulá-los a exteriorizarem, comunicarem, contarem, apresentarem as experiências adquiridas nas trocas sociais de sua trajetória.

Ao se desenvolver um processo musicoterapêutico com grupos, ou individualmente, utiliza-se das técnicas apropriadas para se atingir os objetivos da intervenção, como a improvisação, a recriação e a composição. Os recursos utilizados são aparelhos de som, fitas K7, CDs, instrumentos de percussão, a voz e os movimentos corporais.

\section{A NARRATIVA}

Ecléa Bosi (1994) escreveu um livro sobre as memórias de velhos. Relata, neste trabalho, o resultado de sua pesquisa sobre os depoimentos pessoais de mais de setenta anos, relembrando suas histórias de vida. Considera que o talento do narrador é adquirido na experiência, que ele extrai da vida e da dor sua lição, mas que sua dignidade é contar sobre essa vida, até o fím, sem medo. Diz ainda: " $a$ memória das pessoas dependeria de um processo pelo qual 'fica' o que significa" (p. 63)

Embora a autora aborde o relembrar e o recontar sob o ponto de vista do idoso, fato que matiza o processo com uma conotação existencial de quem revê o vivido como uma contribuição já acabada na construção de uma sociedade, no caso a sociedade de São Paulo, encontramos na análise que fez Bruner (1997), sobre a narrativa de crianças e adultos, considerações semelhantes, porém enfatizando o papel central da cultura na constituição dos conteúdos compartilhados em histórias de vida.

$\mathrm{Na}$ ação musicoterapêutica dá-se ênfase às manifestações que se concretizam por meio da linguagem musical e da linguagem não-verbal. Normalmente as canções trazidas pelas pessoas traçam uma linha do tempo, tal qual as narrativas encontradas em Bosi (1994) e Bruner (1997), contando de suas vidas, resgatando aquilo que "ficou" das suas experiências.

É uma narrativa cantada, que vem carregada de emoção, muitas vezes de voz embargada, que sensibiliza a pessoa a falar de si mesma, a contatar com suas intencionalidades: crenças, desejos, intenções, e a buscar seus significados e sentidos.
Quem narra conta de si, compartilha seus significados buscando conferir sentido e organização ao seu mundo. Bruner (1997) afirma que "uma história é sempre a história de alguém” (p. 53) que convida à reconstrução do que poderia ter acontecido, colocando os eventos no patamar das possibilidades, sob um ponto de vista pessoal.

Bruner percebeu também uma função orientadora na palavra ao refletir que "os seres humanos dão sentido ao mundo contando histórias sobre ele. As histórias são ferramentas, instrumentos da mente em prol da criação de sentido" (Bruner, apud Geertz, 2001, p. 173).

\section{MÉTODO E PROCEDIMENTOS}

Os encontros se realizaram no quarto da paciente. No espaço havia uma cama, uma mesa de cabeceira, um armário, uma poltrona, uma mesinha alta e um frigobar. Os seus pertences estavam acomodados sobre os móveis, decorando o ambiente.

Nas sessões ela sentava-se numa cadeira que era trazida especialmente para esse fim. Nossa disposição física era frente a frente, próximas uma da outra, de forma que ela pudesse visualizar meu rosto, o que facilitava sua audição e domínio visual, já que se queixava de dificuldade para ouvir e ardume nos olhos ao fixar o olhar.

Minha postura como musicoterapeuta foi a de buscar o inter-relacionamento com Chiquita por meio da execução das canções que solicitava, acompanhando-a ao som do pandeiro, instrumento utilizado na maioria das sessões ${ }^{3}$.

Sempre que ela se lembrava de uma nova canção, entoava-a sozinha e sem acompanhamento instrumental. Nas sessões seguintes, como já nos havíamos apropriado da canção, esta era cantada por nós duas e com acompanhamento do pandeiro, sendo repetida em todos os encontros posteriores, agregando-se ao seu repertório anterior.

Chiquita fazia questão de que cantássemos juntas, dizendo que o trabalho era nosso. Quando não se sentia bem de saúde, pedia simplesmente para ouvir a gravação realizada no encontro anterior. Como seu processo teve por base as técnicas musicoterapêuticas da recriação e da audição, nossas interações foram predominantemente melódicas, sendo que poucas vezes minha voz soou sozinha nas sessões. As demandas partiram sempre dela e foi por meio dessas canções que pude estimular a introdução de elementos novos à sua realidade existencial.

A técnica utilizada para a obtenção dos dados foi a gravação das recriações ${ }^{4}$ executadas durante as sessões. O processo de gravação iniciava-se logo após comentarmos suas impressões sobre os fatos concretos ocorridos desde nosso último encontro e sobre seu estado de saúde.

Dados observados durante a intervenção foram anotados em relatório. A cada sessão corresponde um relatório. Foram anotadas observações referentes à linguagem não-verbal, como intensidade e altura da 
voz, reações motoras e movimentos corporais voluntários, direção do olhar, ritmo respiratório e verbalizações.

Os dados foram coletados em 26 sessões individuais de musicoterapia, no período de agosto de 2001 a março de 2002. As sessões foram gravadas em fitas $\mathrm{K} 7$, e as observações anotadas em relatórios diários de sessão.

Utilizou-se a análise do sistema de estímulos presentes nas expressões criativas, como sugere Vygotsky (1990), para proceder ao estudo dos dados. Estabeleceu-se uma relação entre textos das canções, ritmo e ordem de apresentação e sua história de vida, buscando entender a emoção que ocorria no intercâmbio imaginação-emoção enquanto Chiquita trocava com o meio seus sentidos existenciais.

Para a coleta e estudo dos dados utilizou-se a abordagem qualitativa, por se concordar com Sallas (1999) que atribui a esta forma de pesquisa a procura do sentido, do conteúdo das manifestações da vida social, próprias de sujeitos que interagem em um universo possível de significações que se originam das ações e das inter-relações desses sujeitos.

Trataremos, neste estudo, do segundo processo musicoterapêutico de Chiquita, iniciado em agosto de 2001. Para o desenvolvimento dos atendimentos estabeleceu-se um encontro por semana, por se considerar necessário um certo cuidado na introdução de qualquer mudança de rotina na existência de Chiquita.

\section{OBJETIVOS DO PROCESSO MUSICOTERAPÊUTICO}

O processo musicoterapêutico teve como objetivos oportunizar a Chiquita o contato com sua musicalidade, construindo uma consciência de si e do seu passado, bem como estimular a ampliação de seu universo existencial oferecendo-lhe novas experiências, buscando quebrar a rigidez cristalizada de seu espaço vivencial.

\section{DADOS DO PROCESSO MUSICOTERAPÊUTICO}

A dinâmica dos encontros foi se desenvolvendo conforme as demandas da paciente e definiu-se em três momentos distintos. Iniciávamos comentando sobre fatos do seu cotidiano ocorridos no intervalo entre as sessões e depois cantávamos suas canções, gravando toda a produção. $\mathrm{Na}$ segunda fase do encontro fazíamos a audição da fita gravada naquele dia e das músicas interpretadas pelos cantores de sua preferência, gravadas em CDs. Finalizávamos comentando sobre as músicas executadas e ouvidas naquele dia e sobre suas impressões a respeito do encontro.

Quanto aos instrumentos de percussão, o guizo esteve presente nas quatro primeiras sessões, ocasião em que ela o utilizou ao cantar. Aceitou o som do violão nos três primeiros encontros, quando realizou movimentos corporais seguindo ordens cantadas. Da quinta sessão em diante recusou o guizo, queixando-se de que o instrumento provocava dores em sua mão. Disse, ainda, que não queria fazer movimentos corporais e que não gostava do som do violão. Desta forma, a voz e o pandeiro foram os instrumentos que permaneceram nas ações musicoterapêuticas e os recursos mais utilizados foram as canções e seus textos. Estimulei a ampliação de seu repertório musical trazendo canções que se assemelhavam, no ritmo, no tema e no timbre, àquelas suas preferidas. Todas foram rejeitadas. Seu repertório, que permaneceu inalterado por quatorze sessões, compunha-se das seguintes canções: "Cariri", "Urubu Rei", "No Rio", "Coimbra", "Chiquita Bacana", "Jardineira", e os jingles "Vinagre Castelo" e "Lã Filhinha",

No final da décima quinta sessão, referiu-se ao compositor Martinho da Vila e pediu para entoar a canção "Canta, canta".

$\mathrm{Na}$ décima sexta sessão acrescentou ao seu repertório costumeiro a canção "Canta, canta" e entoou um trecho de "Parece que eu sabia". Referiu-se ao intérprete da canção, Wanderlei Cardoso, e pediu para que lhe trouxesse a letra completa da música no encontro seguinte.

$\mathrm{Na}$ vigésima sessão, depois de entoar seu repertório, já acrescido de "Parece que eu sabia" e de ouvir a gravação de "Canta, canta", pediu pela canção "Ciclone" (Adelino Moreira).

Quanto à linguagem musical observou-se que sua expressão musical tinha uma intensidade média e sem variações, o ritmo predominante era o samba e a ordem de apresentação das canções permaneceu a mesma desde o início do processo até a última sessão de levantamento de dados.

\section{ANÁLISE DOS DADOS}

Observando o desenvolvimento do processo de criação musical de Chiquita sob a lente da teoria histórico-cultural, encontrei em Vygotsky (1999) a sugestão de um método de análise do sistema de estímulos apresentados nas expressões criativas. Sugere o autor que se proceda ao estudo dos elementos e da estrutura que constituem a própria expressão, passando, então, para a análise funcional destes mesmos elementos e reconstruindo a emoção estética ou catártica que permeia o ato criativo.

Tratei, então, as letras, o ritmo das canções e a seqüência de apresentação das mesmas como os elementos concretos de maior presença nas expressões criativas analisadas. Estabeleci uma relação entre esses elementos e a história de vida de Chiquita, buscando apreender a emoção que ocorria no intercâmbio imaginação-emoção enquanto ela trocava com o meio seus sentidos existenciais.

Considerei os dados levantados sob a lei do signo emocional comum, proposta por Vygotsky (1990), segundo a qual "todo o elemento causador de efeito emocional semelhante tende a unir-se entre si, mesmo que não haja entre eles nenhuma semelhança interior ou exterior" (p. 22). O autor explica que as imagens se 
combinam reciprocamente por possuírem tom afetivo comum.

\section{ANÁLISE DOS TEXTOS DAS CANÇÕES ${ }^{6}$}

\author{
"No meu Cariri, quando a chuva não vem \\ Não fica lá ninguém, só mesmo quem Deus ajuda \\ Se não vier do céu, chuva que nos acuda \\ Macamira morre, chique-chique seca \\ Juriti se muda." \\ "Se meu Deus der um jeito, se acabaro \\ desengano, \\ se chover todo ano, o meu viver é eterno \\ O meu Cariri, pode-se ver de perto."
}

"Cariri" é sempre a primeira canção entoada nas sessões. O texto descreve um lugar onde chove pouco, as pessoas migram, abandonam as terras e a vegetação morre. Só permanece no local a pessoa quem tem a ajuda de Deus. Apenas o auxílio divino seria capaz de modificar a situação de desengano. Conclui com a expectativa de que algo positivo aconteça para que se possa retornar a esse lugar, ficar perto dele e lá viver eternamente.

\section{"Urubu tirou a dama, mas a dama não dançou, urubu ficou zangado, bateu asas e voou. \\ Urubu não é culpado dessa grande confusão \\ Ele é rei no espaço, mas não é rei no salão \\ Vem cá embaixo, urubu, vem dançar no salão $O$ zangado respondeu: \\ Conheço a confusão, mas não sou eu culpado Dessa grande confusão, sou rei no espaço Mas não sou rei no salão."}

A segunda canção é "Urubu Rei". O texto relata uma cena na qual um animal foi rejeitado por uma personagem do sexo oposto. Ressentido, ele saiu da cena e sumiu. O texto justifica que ele não foi culpado pelo que aconteceu, ele apenas tentava ocupar uma posição num lugar que lhe era estranho. Embora tenha sido convidado, o animal nega-se a regressar ao espaço da cena, mostrando que entendeu seu lugar naquele contexto.

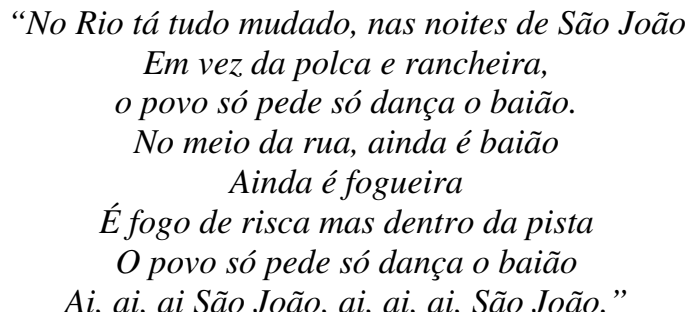

A terceira canção, "No Rio", retrata a dinâmica de uma mudança de costumes, mostrando o rompimento de alguns valores. Já não se faz mais o que se fazia antes. As danças antes preferidas, foram substituídas por outras. Recorre-se a São João, num lamento: ai, ai, ai, ai.

\author{
"Coimbra do Choupal, pra mim és capital \\ Do amor em Portugal, ainda \\ Coimbra onde uma vez, em lágrimas se fez \\ A história desta Inês, tão linda \\ Coimbra dos doutores, pra nós os teus cantores \\ A fonte dos amores, és tu \\ Coimbra é uma lição, de sonho e tradição \\ $O$ lente é uma canção, e a lua faculdade \\ O livro é uma mulher, só passa quem souber \\ E aprende-se a dizer saudade."
}

A quarta peça, seguindo a ordem de apresentação, é "Coimbra", cujo texto exprime romance e sentimentos de saudades. Um determinado lugar, Coimbra, onde existem doutores, cantores e saberes, histórias de amor acontecem. Esse lugar é fonte de tradições, sonhos e saudades.

Há, aqui, a transição concreta de temas regionais e populares para assuntos sentimentais e de maior erudição. $\mathrm{O}$ contato de Chiquita com a realidade do branco de origem européia, com o universo da cultura dominante.

\section{"Chiquita Bacana lá da Martinica Se veste com uma casca de banana nanica \\ Não usa vestido, não usa calção \\ Inverno pra ela, é pleno verão \\ Existencialista com toda razão \\ Só faz o que manda o seu coração."}

A quinta canção, "Chiquita Bacana", trata da irreverência de uma personagem que assume seu corpo vestindo-se com pouca roupa. Não usa vestido nem calção, aceita a realidade da existência humana e "faz o que manda o seu coração".

"Oh, jardineira por que estás tão triste? mas o que foi que te aconteceu? Foi a camélia que caiu do galho Deu dois suspiros e depois morreu Vem jardineira, vem meu amor

Não fique triste que este mundo é todo teu Tu és muito mais bonita que a camélia que morreu."

O diálogo da sexta canção, "Jardineira", indaga o motivo de uma tristeza. A resposta dá conta de uma perda, uma morte. O consolo para essa situação é perceber-se viva e capaz de superar a perda consumada.

“A minha empregada Maria, seja de noite ou de dia Quando não canta, assobia, esse trechinho:

Vinagre Castelo, vinagre Castelo

Vinagre Castelo tempera melhor."

E:

"Vou comprar a lã Filhinha ou então a lã Ipê vou fazer dois casaquinhos bonitinhos como o quê, 
pra conforto do netinho lã Filhinha ou lã Ipê."

São os jingles que encerram a execução melódica de Chiquita. São pequenas canções de cunho comercial, cujos temas remetem à realidade doméstica: objetos, personagens e atributos que se aproximam do cotidiano que vivenciou no dia a dia de seu trabalho.

Todas as canções que reproduz estão em ritmo de samba. Aceitou o acompanhamento do pandeiro, percutido pela terapeuta, trazendo elementos de sua cultura: a percussão e o samba, ritmo que tem origem na música negra trazida pelos escravos.

$\mathrm{Na}$ seqüência do processo, ela inseriu no repertório mais três canções, sendo "Canta, canta" a primeira.

\section{“Canta, canta, minha gente, deixa a tristeza pra lá Canta forte, canta alto, que a vida vai melhorar A vida vai melhorar, a vida vai melhorar Cantei um samba...”}

O texto é um convite para que se abandone a tristeza, afirmando que isso pode ser feito ao se cantar alto e forte. Como consequiência, a vida vai melhorar.

A segunda canção inserida foi "Bom Rapaz".

"Parece que eu sabia que hoje era o dia de tudo terminar, Pois logo notei, quando telefonei, pelo seu jeito de falar. Eu nunca pensei, quem eu tanto amei, fosse assim me desprezar

Mas o mundo é grande, vou não sei pra onde Alguém há de me amar

Já que terminamos só resta agora o adeus final

Te amar demais, ser um bom rapaz, foi o meu mal."

Essa canção retrata uma tensão passional: a percepção de que o relacionamento está prestes a terminar e a sensação do abandono iminente. A personagem declara-se surpresa com a situação que se apresenta, reconhecendo que perante o desprezo, só lhe resta dizer adeus e seguir seu destino no mundo. Justifica-se, concluindo que na sua vida, tudo o que fez foi agir corretamente e amar.

A terceira e última canção admitida no seu repertório foi "Ciclone".

"Ela se enamorou de outro rapaz,

Assim que o ciclone atingiu nossos destinos

Nenhum de nós pensou voltar atrás

Que orgulho, quantos desatinos

Eu bebi champagne em seu noivado

Traguei minha mágoa no peito sem rancor

Fui o primeiro a chegar à igreja e amargurado

Assisti o orgulho matar dois sonhos de amor

Uma noite, já muito tempo depois

Ela veio chorando e chorando

Atirou-se em meus braços

E disse ganhando meus beijos

E disse ao sentir meus abraços

'Sou eu que com fome de amor vem te procurar'
'Sou eu', sua voz doce e meiga com prazer ouvi

'Sou eu que cansei de mentir, de fingir e enganar'

'Sou eu que cansei de outra boca beijar pensando em ti'.",

Esta canção retrata a história de um relacionamento abalado por uma traição. Um terceiro elemento se insere conquistando a pessoa amada. Aquele que ficou sozinho, magoado e amargurado, vai ao casamento, participa da comemoração sentindo morrer seu sonho de amor. Tempos depois, o traidor retorna arrependido e saudoso sendo, então, acolhido aos beijos e abraços.

\section{CONCLUSÃO}

A análise das letras, do ritmo das canções e da ordem de apresentação das mesmas, elementos concretos de maior presença nas recriações de Chiquita, apontou para uma relação entre esses elementos e sua história de vida. Também nos forneceu subsídios para entender a emoção catártica que ocorre no intercâmbio imaginação-emoção enquanto ela troca com o meio seus sentidos existenciais.

A música e as sonoridades são manifestações próprias de cada cultura e tornam-se instrumentos de expressão de sentimentos na medida em que permitem ao ser humano a negociação de seus significados. Chiquita encontrou nos elementos sonoros de sua cultura formas de expressar suas preferências, idéias e sentimentos.

Os textos das canções por ela selecionadas no imenso universo do cancioneiro popular parecem retratar sentimentos e imagens que se assemelham aos fatos da realidade vivida por ela na sua trajetória de vida. Sob esta ótica, suas expressões criativas causaram sentimentos parecidos aos experimentados por ela na construção de sua história, traduzindo, por semelhança de tom afetivo, a dinâmica emocional que mediou suas experiências anteriores. Esses elementos se combinaram, possibilitando a ela a resignificação de seus sentidos.

Ao selecionar suas canções, solicitar outras, rejeitar melodias e sonoridades, organizar a ordem de apresentação e cantar seu repertório, processou um intenso movimento de imaginação e emoção, agindo sobre o meio ao mesmo tempo que por ele foi influenciada.

Se refletirmos como Vygotsky (1999), para quem a alegoria tem por base a semelhança não de palavras, mas de sentido, de essência, a expressão criativa de Chiquita nos traduz o movimento de sua imaginação e emoção em suas trocas sociais. Ela recria sua história na sequiência organizada das canções: a esperança de que o estado das coisas possa vir a ser melhor "Cariri"; o momento da ruptura com valores - "No Rio"; o contato com o meio cultural do branco "Coimbra"; a sexualidade assumida - "Chiquita Bacana"; o consolo e o retorno ao seu antigo modo de ser - "Jardineira" e jingles. Elementos de religiosidade permeiam as canções. 
A alegoria que construiu por meio das letras das canções possibilitou o distanciamento da realidade. Ao isolar-se da objetividade Chiquita pôde refletir, apropriar-se e elaborar seus sentimentos. É este distanciamento da realidade que dá lugar à catarse, processo de elaboração e descarga de energia nervosa que amplia a personalidade, enriquece-a com novas possibilidades e a predispõe para reações, conforme análise de Vygotsky (1999).

As canções que aceita após ter tido a oportunidade de reelaborar suas experiências por meio da narrativa musical parecem realizar uma transição, um movimento de elaboração. São canções que configuram o desprezo, a perda do ser amado para outra pessoa e a esperança de que a vida possa melhorar. Benenzon (1988), teórico da musicoterapia, considera que a canção oferece ao ouvinte a possibilidade de ouvir seus sentimentos cantados por outra pessoa, possibilitando a mediação de emoções a uma distância confortável.

Desta forma, a prática da musicoterapia, mobilizando imaginação e emoção, constituiu um espaço de comunicação em que ela expressou seus conteúdos simbólicos afetivos construídos na suas relações sociais, trazendo-lhe à consciência sua trajetória histórica. Essa reorganização de sentidos por meio da narrativa permitiu que Chiquita pudesse apropriar-se de si mesma, transformar-se numa pessoa que conta de si e se expande através do ato criador.

Retomando a constatação de Bosi (1994) de que "fica o que significa", ao se expressar por meio das canções, Chiquita falou de si mesma, organizando sua interioridade, ouvindo-se, entendendo-se, entrando em contato com seus sentimentos. Reafirmando Bruner (1997), ao organizar os seus conteúdos numa estrutura esquemática, ela pode reconstruir seu mundo sob uma nova ótica.

Esse movimento de organização e reconstrução vem sintetizado nas canções que sugerem a atitude de cantar para tornar a vida melhor já que como o "Bom Rapaz", na sua trajetória de vida, tudo o que fez foi procurar o bem e amar, recebendo como retorno o desprezo e o abandono. Só lhe resta portanto, procurar por outro alguém que há de "lhe" amar.

A última canção que trouxe para seu universo sonoro, "Ciclone", retrata um caso amoroso que guarda similaridades com sua experiência amorosa. Parece que ela precisou realizar uma trajetória organizadora, representada na seqüência rígida de seu repertório, para conseguir enfrentar o contato com uma história semelhante à sua.

Nessa interface psicologia-musicoterapia constatamos alguns aspectos relacionados à mobilização da emoção e imaginação por meio da expressão criativa musical. Este é um estudo de caráter exploratório que evidencia um campo de possibilidades para o desenvolvimento de novos estudos que venham a contribuir com a construção da teoria das ciências aqui implicadas.

A musicoterapia, como ciência nova que é, beneficia-se com estudos científicos que colaborem com sua fundamentação e fortalecimento no meio acadêmico. A música, ferramenta poderosa de articulação das emoções, ainda é pouco pesquisada como linguagem expressiva. Acredito que nos deparamos, aqui, com um campo fértil que poderia contribuir com a compreensão do homem e de suas relações histórico-culturais.

\section{REFERÊNCIAS}

Benenzon, R. (1988). Teoria da Musicoterapia. São Paulo: Summus.

Bosi, E. (1994). Memória e Sociedade: lembranças de velhos. São Paulo: Companhia das Letras.

Bruner, J. (1997). Atos de significação. Porto Alegre: Artes Médicas.

Bruscia, K. (2000). Definindo Musicoterapia. Rio de Janeiro: Enelivros.

Geertz, C. (2001). Nova luz sobre antropologia. Rio de Janeiro: Jorge Zahar.

Leontiev, A. (1978). O desenvolvimento do Psiquismo. Lisboa: Livros Horizonte Ltda.

Ruud, E. (1998). Music Therapy: improvisation, communication and culture. Barcelona: Barcelona Publishers.

Ruud, E. (1990). Los camiños de la musicoterapía. Buenos Aires: Bonum.

Sallas, A. L. F. (1999). Os jovens de Curitiba: desencantos e esperanças, juventude, violência e cidadania. Brasília: Unesco.

Teplov, R. M. (1977). Aspectos psicológicos de educação artística. Em Luria, Leontiev, Vigotsky e outros, Psicologia e Pedagogia II (pp. 123-153). Lisboa: Editorial Estampa.

Vygotsky, L. S. (1990). La imaginación e el arte en la infancia. Madrid: Akal.

Vygotsky, L. S. (1993). Obras Escogidas II. Madrid: Visor Distribuciones.

Vygotsky, L. S. (1999). Psicologia da Arte. São Paulo: Martins Fontes. 


\section{Notas:}

${ }^{1}$ A linguagem musical corresponde, neste estudo, aos elementos que a pessoa utiliza para expressar sua musicalidade: canções e seus textos, melodias, ritmos, timbres, intensidades, alturas, ruídos, poesias e outras expressões sonoras que possibilitem a comunicação de estados intencionais.

${ }^{2}$ Segundo o autor, o caminho não é tão linear como parece, o desenvolvimento pode deter-se em qualquer momento deste complicado percurso. Entre o pensamento e a palavra as relações são delicadas e é possível uma variedade de movimentos que ainda não conhecemos.

${ }^{3}$ Foram selecionados três instrumentos de percussão para a execução do acompanhamento das vozes: guizos, violão e pandeiro. Entre os materiais que eram utilizados nas sessões estavam o aparelho de som, CDs com músicas das décadas de 30 e 50 , um gravador e fitas K7.

${ }^{4}$ Recriação é a reprodução de canções. No caso aqui exposto, Chiquita recriava as canções que ouvia no rádio, nos seus tempos de juventude

${ }^{5}$ As canções conservam o nome pelo qual são chamadas por Chiquita. No momento realizo uma busca pelas rádios, no intuito de conseguir a gravação original dessas melodias, para relacionar seus verdadeiros títulos e autores, dados que pretendo anexar ao estudo.

${ }^{6}$ Os textos das canções foram literalmente transcritos conforme gravados durante as sessões.

\section{Sobre as autoras}

Denise de Camargo: Dr $^{\mathrm{a}}$ em Psicologia Social pela PUC de São Paulo. Professora do Mestrado em Psicologia da Infância e Juventude da Universidade Federal do Paraná.

Yara Lucia M. Bulgacov: Dr ${ }^{\mathrm{a}}$ em Psicologia. Professora do Mestrado em Psicologia da Infância e Juventude da Universidade Federal do Paraná.

Rosemyriam Cunha: Musicoterapeuta. Gerontóloga pela SBGG. Mestranda em Psicologia da Infância e da Juventude pela Universidade Federal do Paraná. Endereço para correspondência: Av. Paraná, 1.634 - 82510-000 Curitiba - PR - E-mail: rose05@uol.com.br. 